Katarzyna Burska

\title{
$O$ analityzmach i syntetyzmach leksykalnych w publicystyce sportowej - na przykładzie peryfraz i uniwerbizmów
}

Językoznawcy podkreślają, że jedną z głównych cech współczesnej polszczyzny jest ekonomia środków językowych. Przejawia się ona w używaniu skrótów i skrótowców, wprowadzaniu do tekstów kontaminacji, uniwerbizmów, złożeń, derywatów, które mają za zadanie przekazywać bogate treści w skondensowanej formie. Czy ta zasada obowiązuje też w artykulach publicystycznych dotyczących sportu? Czy może wciąż aktualne są założenia Kniagininowej [Kniagininowa 1963], która twierdziła, że znamienną cechą stylu dziennikarskiego są struktury opisowe? Czy konstrukcje peryfrastyczne mogą służyć do ekonomicznego wyrażania myśli? Jakie funkcje pełnią w publicystce sportowej wyrażenia omowne, a kiedy dziennikarze sięgają po określenia zuniwerbizowane? Celem artykułu jest przedstawienie analitycznych konstrukcji leksykalnych w prasie sportowej, które mają syntetyczne odpowiedniki. Zjawisko to zostanie zanalizowane na przykładzie peryfraz, orzeczeń peryfrastycznych oraz uniwerbizmów.

W niniejszym opracowaniu za analityzm leksykalny uznaje się co najmniej dwuwyrazowe określenie, które posiada jednowyrazowy odpowiednik tożsamy lub bliski znaczeniowo'. Do konstrukcji

1 Jest to szerokie ujęcie prezentowanego fenomenu językowego. Anusiewicz, autor monografii poświęconej konstrukcjom analitycznym (zwanych przez niego też opisowymi), wyjaśnia, że są to „takie niewspółrzędne związki wyrazowe, które współistnieją obok znaczeniowo im ekwiwalentnych prostych (jednordzeniowych) wyrazów, przy czym morfem leksykalny wyrazu 
analitycznych zaliczane więc będą peryfrazy czy orzeczenia peryfrastyczne, które da się zastąpić określeniem jednowyrazowym - niezależnie od tego, czy zawierają one wspólne morfemy z odpowiadającymi im syntetyzmami leksykalnymi. Jako podstawa badawcza posłużą jednostki leksykalne pochodzące z czterech stałych rubryk publicystycznych obecnych na łamach tygodnika „Piłka Nożna”: „Krótka piłka” Adama Godlewskiego, „Na żywo, czasem w studio” Macieja Iwańskiego, „Futbolowy high life” Kazimierza Oleszka oraz „Ze środka obrony” Władysława Żmudy. Materiał egzempflikacyjny pochodzi z 23 numerów tygodnika „Piłka Nożna” - od listopada 2011 roku do kwietnia 2012 roku.

\section{Peryfrazy}

Bardzo dużą grupę konstrukcji analitycznych mających syntetyczne odpowiedniki stanowią peryfrazy. Jak definiuje Bańko, jest to „wielowyrazowe określenie osoby, rzeczy, miejsca lub pojęcia, używane zwykle ze względów ornamentacyjnych lub eufemizacyjnych, a więc dla ozdobienia lub złagodzenia wypowiedzi. (...) Cechą wspólną obu rodzajów peryfraz jest ich funkcja estetyczna" [Bańko 2002b: 5]. Badacz dodaje też, że peryfraza to „wyrażenie złożone o charakterze opisowym lub przenośnym, nazywające nie wprost i zastępujące nazwę właściwą" [Bańko 2002a: 5].

podrzędnego wchodzącego w skład danej konstrukcji jest tożsamy substancjalnie z morfemem leksykalnym wchodzącym w skład odpowiadającej jej formy prostej wyrazu" [Anusiewicz 1978: 22]. Zgodnie z tymi założeniami struktury opisowe mają więc zawierać część ekwiwalentnego im znaczeniowo wyrazu prostego [Anusiewicz 1978: 23]. Cockiewicz postuluje przyjęcie tez Anusiewicza w lagodnej formie i jako kryterium proponuje tożsamość znaczeniową [Cockiewicz 2000: 145]. Miodek z kolei mianem leksykalnych konstrukcji syntetycznych określił „formacje słowotwórcze (utworzone za pomocą różnego rodzaju formantów), w których dochodzi do zastąpienia połączeń dwu- lub kilkuwyrazowych jednym określeniem” [Miodek 1976: 6]. 
Zdecydowanie najliczniej w badanym materiale występują wyrażenia omowne zastępujące oficjalne nazwy geograficzne. Można wśród nich wyróżnić takie, które porównują polskie miasta do ich zagranicznych odpowiedników: Łódź została nazwana polskim Manchesterem ze względu na obecność zakładów przemysłu włókienniczego i odzieżowego. Omówienie to ma zdobić, świadczy o erudycji dziennikarza, zmusza także czytelnika do wykorzystania wiedzy pozajęzykowej. „Peryfrazy tego typu stanowią swoistą hiperbolę, akt nobilitacji dla mniej znanych denotatów" [Straś 2001: 104]: Społeczeństwo zawsze mieliśmy ofiarne, ale łódzkie szwaczki nie należą do bogatej kasty, co prężniejsze zakłady pracy w polskim Manchesterze te $\dot{z}$ już dawno odwrócity się plecami do pitkarzy. (PN 5/2012, s. 47); O problemach pitkarzy z alei Unii kibice słysza nieprzerwanie od kilku, jeśli nie kilkunastu, sezonów i prawdę mówiąc, przyzwyczaili się już, że $w$ Łodzi albo zapowiadaja strajk, albo już są w jego trakcie. (PN 5/2012, s. 47).

Paryż z kolei mianowano stolica mody i perfum, odwołano się więc do właściwości, z których słynie stolica Francji. Wprowadzone omówienie współgra z tematyką artykułu, harmonizuje z wyrazami użytymi w zdaniu: David B., jako jeden z ekspertów od wody kolońskiej po goleniu, czułby sie jak ryba w wodzie w stolicy mody i perfum. (PN 45/2011, s. 29); Poza tym z terminalu St Pancras Station $w$ Londynie do znajdujacej się w centrum Paryża Gare du Nord można się przemieścić pociagiem pod kanałem La Manche w czasie nieprzekraczajacym dwóch godzin. (PN 45/2011, s. 29).

$\mathrm{W}$ celach ornamentacyjnych posłużono się wyrażeniem omownym miasto Beatlesów, które pojawiło się obok tradycyjnej nazwy miasta $\mathrm{w}$ ramach dopowiedzenia, dodatkowego wyjaśnienia, które ma tylko uatrakcyjnić tekst, nie jest niezbędne do właściwego odczytania przekazu zawartego w zdaniu: Liverpool, czyli miasto Beatlesów, jest położony na zachodnim wybrzeżu pótnocnej Anglii, około $340 \mathrm{~km}$ od Londynu, na pótnocnym brzegu estuarium rzeki Mersey. (PN 15/2012, s. 37).

Peryfrastyczne określenia przylgnęły nie tylko do nazw miast, ale także kontynentów. Afryka bywa określana Czarnym Lądem lub Czarnym Kontynentem, Europa zaś - Starym Kontynentem. Wprowadzanie wielowyrazowych zamienników służy funkcjom zdobniczym, synonimiczne określenia wzbogacają lekturę, pozwalają uniknąć powtórzeń: 
Rozgrywany w cyklu dwuletnim turniej ma status mistrzostw Czarnego Kontynentu. (PN 46/2011, s. 33); Bo przecież będzie selekcjonerem najbardziej utytułowanego narodowego teamu na Czarnym Lądzie. (PN 44/2011, s. 29); Jednak dowodzi to także, że w Afryce poziom rywalizacji bardzo się wyrównat albo - jak kto woli - mocno spuścity z tonu dawne potęgi. (PN 46/2011, s. 33); Pierwsze odbywaja się wtaśnie w Serbii, a wytonia najlepsza na Starym Kontynencie drużynę pitki ręcznej. (PN 4/2012, s. 11); Serbia jako kraj czeka na referendum w sprawie akcesji do Unii Europejskiej, jednak jej pitkarskie kluby znajdują się w elicie Europy na pewno. (PN 4/2012, s. 11).

Wyobrażenia mieszkańców Chin o potędze zamieszkiwanego przez nich terytorium odzwierciedla peryfraza Państwo Środka: Jednak to nie koniec informacji z Państwa Środka. (PN 51-52/2011, s. 89). Z kolei analityczne określenie Wyspa Afrodyty odwołuje do popularnego na Cyprze mitu głoszącego, że u brzegów tej wyspy narodziła się grecka bogini miłości. Rozszyfrowanie użytej w tekście peryfrazy wymaga od odbiorcy chociaż podstawowej znajomości mitologii: Chyba wszyscy byliśmy zdziwieni klasa APOEL, ale po porażce z Cypryjczykami $z$ Krakowa plynęty sygnaty, że zespót $z$ Wyspy Afrodyty tylko $w$ dwóch aspektach przebija Wistę. (PN 45/2011, s. 2).

Formę wyrażenia omownego ma także przydomek Super Orty ${ }^{2}$ odnoszący się do piłkarzy reprezentujących Nigerię. Można go uznać za peryfrazę specjalistyczną, którą właściwie zinterpretować mogą jedynie kibice piłki nożnej. $\mathrm{W}$ analizowanym artykule tylko raz pojawia się omówienie, trzykrotnie zaś jednoelementowa nazwa właściwa, co pozwala naprowadzić odbiorców na pożądany przez dziennikarza sens odczytania: Fankluby reprezentacji Super Ortów rozsiane sa w wielu krajach. (PN 46/2011, s. 33); Wielkim nieobecnym jest także Nigeria, a więc kraj, który eksportuje największa po Brazylii i Argentynie liczbę pitkarzy do różnych lig na kilku kontynentach. (PN 46/2011, s. 33).

2 Zgodnie z polskimi zasadami ortograficznymi wyrazy z przedrostkiem super- należy pisać łącznie i wówczas byłby to syntetyzm leksykalny, przydomek ten funkcjonuje jednak jako nazwa składająca się z dwóch elementów i dlatego może być zaliczony do konstrukcji analitycznych. 
Alternatywne nazwy miast czy krajów często zawierają element charakterystyczny dla danego terytorium, w zgromadzonym materiale były to przede wszystkim nazwy rzek. Posługiwanie się takimi peryfrazami zakłada, że czytelnik ma elementarne wiadomości z zakresu geografii. Stambut został nazwany metropolia nad Bosforem, Francja określana jest jako kraj nad Sekwana, Polska zaś to piękny kraj nad Wisłą czy obszar między Bugiem a Odrą: Kiedy znudziło mu się życie w metropolii nad Bosforem, wrócit do Premier League, by bronić najpierw barw Boltonu, a ostatnio Chelsea. (PN 51-52/2011, s. 89); Jeden z nich dotyczy pitkarzy i trenera $w$ kraju nad Sekwana. (PN 13/2012, s. 20); O to samo chciałbym zapytać odpowiedzialnych za arbitrów i asystentów w pięknym kraju nad Wistą. (PN 49/2011, s. 33); Po tym jak w polskiej grupie znalazły się reprezentacje Grecji, Rosji i Czech, między Bugiem a Odra zapanowata wielka euforia. (PN 49/2011, s. 47).

Za pomocą peryfraz określa się nie tylko nazwy miast, krajów czy kontynentów, ale także narodowości. Syntetyczna forma Żyd została rozwinięta analityczną konstrukcją nacja stynąca $z$ biznesowej żytki, co uwypukla, na jakie cechy narodu żydowskiego chciał zwrócić uwagę autor artykułu, i równocześnie wartościuje: A skoro tak uważa Grant, czyli $\dot{Z} \boldsymbol{y d}$, a więc człowiek nacji stynącej z biznesowej żytki, to musi być w tym duża porcja prawdy. (PN 51-52/2011, s. 89).

Występujące w publicystyce piłkarskiej peryfrazy służą nie tylko celom zdobniczym, zdarza się, że wprowadzane są po to, by złagodzić przekazywane treści. I tak, nieskuteczność nazwano eufemistycznie niemoca strzelecka - połączenie to można potraktować jako specjalistyczne, zrozumiałe dla użytkowników socjolektu sportowego: Mario Gomez przed przedostatnim meczem ligowym Bayernu z VfB Stuttgart naczytat się i nastuchat sporo krytycznych uwag o swojej niemocy strzeleckiej. (PN 1/2012, s. 35).

Współcześnie przyjęło się, że korupcja to temat, o którym nie mówi się głośno. W tym celu używa się przybierających formę peryfraz eufemizmów - korupcja jest więc czerpaniem korzyści majątkowych,

3 Peryfraza kraj nad Wista została poprzedzona wartościującym dodatnio przymiotnikiem piękny, co wpływa na jej pozytywny odbiór przez czytelników. 
a łapówka - wspomnianą korzyścia majątkowa: Wybrany z ramienia Partii Socjalistycznej próbuje uderzać w tych, którzy mają najwięcej pieniędzy albo dorobili się, nie daj Boże, na korupcji. (PN 48/2011, s. 29); Chodziło o to, że część wysokiej rangi działaczy FIFA mogła wziąć tapówki od ISL. (PN 48/2011, s. 29); Drugim podejrzanym o czerpanie korzyści majątkowych $z$ racji zajmowanego stanowiska jest były zięć Havelange'a, prezydent konfederacji futbolu Brazylii Ricardo Teixeira. (PN 48/2011, s. 29).

Podobną rolę odgrywa sformułowanie odbieranie $\dot{z} y c i a$ zamiast zabijanie - zastosowany analityzm leksykalny ma zdecydowanie łagodniejszą wymowę od bliskiego znaczeniowo syntetyzmu: Widać przez niego szaleńca, który po objęciu wtadzy ogłosit się Bogiem i dat sobie prawo do odbierania życia. (PN 6/2012, s. 11).

Peryfraza może być także nośnikiem ironii. Sędzia czy arbiter to wyrazy nienacechowane, oprócz nich w artykule dotyczącym pomyłek popełnianych przez prowadzących zawody pojawiło się prześmiewcze omówienie biegacze z gwizdkami: Zwłaszcza w czasach zarazy, kiedy biegacze $z$ gwizdkami myla się (...) na potęgę w każdej rozgrywanej kolejce. (PN 44/2011, s. 2); Sędzia Robert Małek nie ustrzegt się rażących pomyłek (...). (PN 44/2011, s. 2); O to samo chciałbym zapytać odpowiedzialnych za arbitrów $i$ asystentów w pięknym kraju nad Wistą. (PN 49/2011, s.33).

Za pośrednictwem syntetycznych i analitycznych form może zostać wyrażona informacja dotycząca wyniku. Wydaje się, że zarówno remis, jak i jego analityczny odpowiednik podziat punktów mają taki sam, nienacechowany wydźwięk, choć jednoelementowe określenie używane jest częściej: Trójkolorowi prowadzeni przez Houlliera do awansu potrzebowali tylko remisu. (PN 13/2012, s. 20); I rzeczony podziat punktów (1:1) widniat na tablicy wyników jeszcze kilkadziesiąt minut przed zakończeniem meczu. (PN 13/2012, s. 20).

\section{Orzeczenia peryfrastyczne}

Obok wyrażeń omownych warto także wyróżnić orzeczenia peryfrastyczne. Kolokacje werbo-nominalne są wykładnikami jednego pojęcia [Vetulani 2001: 59]. Nierzadko dziennikarze posługują się opisową formą dać (sobie) radę, której odpowiada syntetyczne poradzić. 
Wydaje się, że dwuwyrazowe zestawienie ma bardziej potoczny charakter niż jego jednoelementowy odpowiednik: Poza wszystkim jednak - już raz nie dat rady $w$ pracy $z$ EKS po letnich przygotowaniach wytrwat na posadzie zaledwie jedna kolejkę. (PN 7/2012, s. 2).

W zgromadzonym materiale wyodrębniono także konstrukcje składające się z bezokolicznika mieć i rzeczownika lub wyrażenia przyimkowego. Zamiast tudzić, watpić czy pamiętać posłużono się peryfrazami czasownikowymi: Ale teraz niech nikt nie ma ztudzeń. (PN 51-52/2011, s. 89); Zatem etykieta zostata zachowana, nikt nie mógt mieć wątpliwości, że występuje reprezentacja kraju, nie zaś federacji. (PN 46/2011, s. 2); Ma bardzo dobrych zawodników, ma w pamięci świeży sukces, którym było wywalczenie Pucharu Polski z Michałem Probierzem na ławce (...). (PN 10/2012, s. 2).

Syntetyczny czasownik wyzywać przyjął w artykule publicystycznym formę złożoną obrzucić wyzwiskami, która ma wymiar eufemistyczny: (...) wyśpiewane przy wyniku 3:0 E viva Espana dowodzi, że polski fan może inteligentnie zakpić z rywala, nie zaś tylko obrzucić go wyzwiskami. (PN 9/2012, s. 11).

Nieraz orzeczenia peryfrastyczne nadają wypowiedzi wzniosłości, analityczne formy ponieść porażkę (zamiast przegrać) i odnieść zwycięstwo (zamiast zwyciężyć) służą wyolbrzymieniu przegranej lub gloryfikowaniu wygranej: Owszem, ponosza też porażki, bolesne, jak choćby $z$ PSV Eindhoven, ale chcę wierzyć, że będa solidna lekcja pokory dla trenera i pitkarzy z Łazienkowskiej. (PN 50/2011, s. 47); Podczas pierwszego podejścia $w$ fazie grupowej, przedstawicielom Wyspy Afrodyty z Marcinem Żewtakowem i Kamilem Kosowskim w składzie nie udało się odnieść żadnego zwycięstwa. (PN 11/2012, s. 34).

Takim samym celom - czyli wprowadzeniu przynajmniej pozornego patosu - podporządkowane jest użycie wielowyrazowych orzeczeń prowadzić drużynę czy prowadzić z ławki trenerskiej, które zastępują pospolite trenować: Jego następca, Amerykanin z krwi i kości, nigdy nie prowadzit drużyny poza granicami Stanów Zjednoczonych. (PN 44/2011, s. 29); Tak czy inaczej po prawie 40 latach, gdy zdążyli odcisnąć piętno na zespołach, które prowadzili z lawki trenerskiej $w$ różnych krajach, obaj panowie wciąż nie mają o sobie najlepszego zdania. (PN 50/2011, s. 29). 
Zdarza się, że jest zupełnie odwrotnie - w miejsce neutralnego określenia wprowadzany jest synonimiczny potocyzm, który czyni tekst bardziej przystępnym. Dzieje się tak w przypadku wielowyrazowego określenia zainkasować komplet punktów, którego syntetycznym odpowiednikiem jest wygrać: Pozostajace wiosna bez wygranych - gdańska Lechia i Łódzki KS - w minionej kolejce wreszcie zainkasowaty komplety punktów. (PN 14/2012, s. 47).

Wielowyrazowe określenia służą także złagodzeniu treści - zamiast przegrać pojawia się gubić punkty, tracić oczka czy nie zdobyć punktów: Jesienia po każdym potknięciu liderującego Ślaska Legia także obowiązkowo gubita punkty. (PN 13/2012, s. 2); Wiosna prowadza już co prawda warszawianie, ale nadal nie zachwycaja i traca kolejne oczka (...). (PN 13/2012, s. 2); Oprócz przegranego meczu z Butgaria nie potrafili także zdobyć punktów w spotkaniu z Izraelem, mimo prowadzenia u siebie 2:1, przegrali 3:2. (PN 13/2012, s. 20).

\section{Uniwerbizmy}

Na uwagę zasługuje też posługiwanie się uniwerbizmami i ich wielowyrazowymi odpowiednikami. Szczepańska definiuje pojęcie uniwerbizacji jako „proces tworzenia określenia jednowyrazowego z wyrażenia dwu- lub kilkuwyrazowego. Nowo powstałe określenie jest synonimiczne w stosunku do motywującej je nazwy i istnieje obok niej równolegle w języku" [Szczepańska 1992: 129]. Określenia zuniwerbizowane są o wiele bardziej nasycone potocznością niż ich analityczne odpowiedniki. Niektóre uniwerbizmy są charakterystyczne wyłącznie dla słownictwa sportowego, można do nich zaliczyć powstałe w wyniku elipsy deadiektywizującej syntetyzmy ławka (na określenie ławki rezerwowych lub ławki trenerskiej) oraz igrzyska (na określenie igrzysk olimpijskich), elipsy substantywizującej karny (na określenie rzutu karnego) czy dezintegracji róg (na określenie rzutu rożnego). Należy podkreślić, że sformułowania te są stosowane wymiennie, często współistnieją w jednym artykule: Henry wszedt $z$ tawki $w 68$ minucie i $w$ piatym kontakcie $z$ pitka strzelit zwycięskiego gola. (PN 3/2012, s. 35); W kolejnym meczu, wygranym z Luksemburgiem, Pawłowski nie zagrał, odpoczywat na 
tawce rezerwowych. (PN 47/2011, s. 47); Po 4165 dniach przerwy na lawce w meczu Bundesligi zasiadl Otto Rehhagel. (PN 10/2012, s. 39); Piętnaście lat później Jovanić prowadził ten klub z lawki trenerskiej przeciwko Realowi Madryt. (PN 14/2012, s. 37); Ileż kontrowersji wzbudziło przyznanie igrzysk 2008 roku Chinom i ile przy okazji mówiono o prawach człowieka $w$ tym kraju lub sytuacji $w$ Tybecie. (PN 6/2012, s. 11); Wystarczy wspomnieć igrzyska olimpijskie w 1936 roku. (PN 6/2012, s. 11); Warszawianie mieli też sporo szczęścia - puchar zdobyli po karnych, a w stynnym już meczu ze Spartakiem w Moskwie los też się do nich uśmiechnąt. (PN 50/2011, s. 16); Chodzito o zabawę, polegajaca na strzelaniu rzutów karnych. (PN 12/2012, s. 11); Zamiast utrzymać ja $w$ tej okolicy, czyli osłaniać lub ewentualnie spróbować wywalczyć róg lub aut, wstrzelit futbolówkę w pole karne. (PN 13/2012, s. 20); (...) na pewno mniejszym btędem bytoby podyktowanie jedenastki dla zespotu Tomasza Kafarskiego (...) niż niedostrzeżenie, iż po rzucie rożnym Marek Wasiluk niedopuszczalnie staranował bramkarza przyjezdnych, młodziutkiego Wojciecha Pawłowskiego. (PN 44/2011, s. 2).

Najbardziej rozpowszechnionym uniwerbizmem pojawiającym się - z racji mistrzostw Europy organizowanych w Polsce i na Ukrainie - chyba we wszelkich możliwych środkach masowego przekazu jest powstały w wyniku dezintegracji wyraz Euro. Warto podkreślić, że w publicystyce o tematyce piłkarskiej często towarzyszy mu rok rozgrywania mistrzostw, który pozwala w ekonomiczny sposób doprecyzować, o który turniej chodzi: $W$ czerwcu $w$ finałach mistrzostw Europy zaakcentują swój udział wybrańcy Franciszka Smudy i wierzymy, że będziemy ich wspierać dłużej niż w trzech meczach fazy grupowej. (PN 2/2012, s. 47); Już za sto kilka dni skończy się Euro 2012, a nam pozostanie kilka wielkich stadionów. (PN 12/2012, s. 11); Przed Euro '96 w Anglii głośno było o konflikcie czarnoskórych kadrowiczów pochodzących głównie z Surinamu z biatymi. (PN 50/2011, s. 29); Chcac osiagnać na Euro zadowalajacy wynik, nie można oceniać poziomu poszczególnych drużyn i modlić się o wylosowanie najsłabszych rywali. (PN 49/2011, s. 47).

O randze tego turnieju świadczy także peryfrastyczne określenie najważniejsze sportowe wydarzenie dekady, a może $i$ ćwierćwiecza: Ze względu na finałowy turniej mistrzostw Europy, którego uroczyste 
rozpoczęcie nastapi 8 czerwca $w$ Warszawie, zaczynamy $z$ niepokojem odliczać dni dzielące nas od najważniejszego sportowego wydarzenia dekady, a może i ćwierćwiecza. (PN 13/2012, s. 47).

Na łamach „Piłki Nożnej” pojawiają się uniwerbizmy przynależne nie tylko do stylu publicystyczno-dziennikarskiego, ale także te używane $\mathrm{w}$ różnych odmianach polszczyzny. Można do nich zaliczyć utworzone dzięki derywacji sufiksalnej zawodówkę i podstawówkę - potoczne określenia szkoły zawodowej i szkoły podstawowej - czy rzecznika powstałego w wyniku redukcji członu przymiotnikowego prasowy: I dodawat, że mógt się akurat tego spodziewać - nadal mowa o trenerze Lenczyku - po człowieku, który jest po budowlanej zawodówce. (PN 44/2011, s. 2); I tylko najwięksi geniusze potrafia przeskoczyć bezboleśnie z podstawówki od razu do szkoły wyższej z pominięciem gimnazjum i liceum. (PN 10/2012, s. 2); Zatrudniono ładna dziewczynę jako rzecznika, na pozycję szefa marketingu ściagnięto fachowca z korporacji, który miat ze związkiem swoje związki wcześniej. (PN 46/2011, s. 11).

Wspomniany rzecznik otrzymał także peryfrastyczne określenie szef stużb prasowych, które pozornie podkreśla jego rangę, ale w rzeczywistości ma zabarwienie ironiczne: Szanuję zdanie szefa stużb prasowych banku, tylko do końca nie godzę się ze stwierdzeniem, że wtaściciel BRE - niemiecki Commerzbank - nie lubi futbolu i nie reklamuje się na pitkarskich arenach. (PN 13/2012, s. 2).

Procesom uniwerbizacji podlegają też nazwy własne. Wybudowany w Warszawie z okazji czempionatu Europy Stadion Narodowy bywa nierzadko nazywany Narodowym. Redukcja członu następuje ze względów ekonomii językowej, nie utrudnia jednak czytelnikom właściwego odbioru - jednoznacznie wiadomo, który obiekt opisują dziennikarze. Uniwerbizm ten pojawia się w tekstach publicystycznych równie często jak pełna nazwa: Planowanym miejscem finałowego meczu PP miat być - jak wiadomo - Stadion Narodowy. (PN 13/2012, s. 47); Potem, $w$ sumie już ze trzy razy, przesuwano termin wstępnej inauguracji Narodowego. (PN 5/2012, s. 2).

Warto zwrócić uwagę na jeszcze jeden sposób współwystępowania konstrukcji syntetycznych $\mathrm{z}$ analitycznymi - przechodzenie dwuwyrazowej nazwy w uniwerbizm i jednocześnie tworzenie rozbudo- 
wanego określenia peryfrastycznego: wspomniany Stadion Narodowy funkcjonuje jako Narodowy, ale przynależne mu są także rozbudowane formy, które wskazują na charakterystyczne cechy stadionu: jego funkcje, przeznaczenie, położenie, koszty budowy i pozycję na tle innych aren sportowych w Polsce. Użycie takich konstrukcji pozwala na precyzyjne dookreślenie i zwraca uwagę czytelnika na konkretne elementy: Główna polska arena finatów Euro 2012 została oddana do użytku. (PN 5/2012, s. 2); (...) na petne i bezwarunkowe oddanie do użytku sztandarowego stadionu w kraju poczekamy do mistrzostw Europy. (PN 6/2012, s. 2); Chciat wynajać nasz reprezentacyjny stadion na kilka godzin, dla potrzeb kilkudziesięciu osób. (PN 12/2012, s. 11); (...) na naszym sztandarowym obiekcie nie ma jeszcze... boiska. (PN 51-52/2011, s. 9); Nowy wspanialy obiekt pitkarski jednocześnie podnióstby rangę wyjątkowo mało prestiżowego i traktowanego $w$ Polsce po macoszemu turnieju tysiąca drużyn. (PN 13/2012, s. 47); Kiedy bowiem (...) najlepiej jest sprawdzić wszystkie procedury, zabezpieczenia i ogólne funkcjonowanie najdroższego - a zatem pewnie (choć wcale nie na pewno) także najnowocześniejszego i najbardziej funkcjonalnego - obiektu pitkarskiego $\boldsymbol{w}$ Polsce? (PN 6/2012, s. 2); Ktoś powie: pomieszanie $z$ poplataniem, $i$ zapewne będzie miat rację, bo $w$ kwestii reprezentacyjnego obiektu wybudowanego w stolicy nie wiadomo, czy lepiej się śmiać, czy raczej płakać. (PN 6/2012, s. 47); Dziś już wiemy, że nie tylko Superpuchar, ale również Puchar Polski otrzymat zakaz wstępu na imponujący i monumentalny obiekt usytuowany po drugiej stronie Wisty, ale jednak na wprost Patacu Kultury i Nauki. (PN 13/2012, s. 47).

\section{Podsumowanie}

Publicyści piszący na łamach tygodnika „Piłka Nożna” chętnie sięgają po analityzmy leksykalne, które mają syntetyczne odpowiedniki. W publicystyce sportowej pojawiają się niejednokrotnie specjalistyczne wielo-lub jednowyrazowe określenia zrozumiałe tylko dla wąskiego grona odbiorców, zainteresowanego opisywaną tematyką. Nie brakuje jednak również peryfraz czy uniwerbizmów stosowanych we wszystkich odmianach językowych polszczyzny. 
Wydaje się, że oba zjawiska językowe są w powszechnym użyciu w tekstach publicystycznych, choć można dostrzec lekką dominację konstrukcji analitycznych. Wpływ na językowy sposób wyrażania treści ma z pewnością gatunek - publicystyka sprzyja wprowadzaniu do artykułów dłuższych, opisowych, pełniących funkcję estetyczną form ozdobnych (jak chociażby peryfrazy) w przeciwieństwie do tekstów informacyjnych, w których najważniejszy jest szybki, zrozumiały, trafny przekaz, nie zaś bogactwo środków leksykalnych.

Konstrukcje opisowe pozwalają niejednokrotnie na precyzyjne wyrażenie myśli, posługiwanie się wyrażeniami omownymi wzbogaca, urozmaica artykuł, ale też wymaga aktywnej postawy odbiorcy. Peryfrazy mogą pełnić różne funkcje w analizowanych felietonach. Służą czasem opisaniu postawy emocjonalnej dziennikarza, a także wartościowaniu - mogą zawierać ironiczny komentarz czy kumulować pozytywne informacje. Bywa też tak, że to jednowyrazowe odpowiedniki mają silniejszy wpływ na odbiorcę, czynią tekst patetycznym. Uniwerbizmy pozwalają z kolei na wyrażenie bogatej treści w maksymalnie skondensowanej strukturze, charakteryzują się potocznością. Wiele opisowych form pełni funkcje eufemistyczne - mimo że publicystyka umożliwia dziennikarzowi wyrażanie własnych poglądów, to nie zawsze chce on nazywać wprost opisywane zjawiska. Stosowanie analitycznych i syntetycznych konstrukcji przynależnych do języka potocznego pozwala zaś na skrócenie dystansu między nadawcą a odbiorcą. Z jednej strony, publicyści „Piłki Nożnej" dążą do ekonomii językowej, z drugiej zaś - by jasno wyrazić swoje zdanie - sięgają po struktury opisowe. Tendencje te wzajemnie się przenikają.

\section{Bibliografia}

Anusiewicz J. [1978], Konstrukcje analityczne we wspótczesnym języku polskim, Zakład Narodowy im. Ossolińskich, Wrocław.

Bańko M. [2002a], Peryfrazy w naszym życiu, „Poradnik Językowy”, z. 9. Bańko M. [2002b], Stownik peryfraz, czyli wyrażeń omownych, Wydawnictwo Naukowe PWN, Warszawa. 
Cockiewicz W. [2000], Konstrukcje analityczne w języku polskiej telewizji w latach siedemdziesiątych i dziś, [w: ] Język w mediach masowych, Bralczyk J., Mosiołek-Kłosińska K. (red.), Upowszechnianie Nauki - Oświata „UN-O”, Warszawa.

Kniagininowa M. [1963], Struktury opisowe - znamienna cecha stylu dziennikarskiego, ,Język Polski”, z. 2.

Loewe I. [2010], Konstrukcje analityczne w polskiej telewizji na progu drugiej dekady XXI wieku, „Stylistyka” XIX.

Miodek J. [1976], Syntetyczne konstrukcje leksykalne w języku polskim, Zakład Narodowy im. Ossolińskich, Wroclaw.

Straś E. [2001], Peryfrazy w środkach masowego przekazu (na materiale prasy polskiej i rosyjskiej), [w:] Konfrontacje języków słowiańskich na poziomie leksyki, słowotwórstwa i składni, Czerwiński P. (red.), Wydawnictwo Uniwersytetu Śląskiego, Katowice.

Szczepańska E. [1992], O dezintegracji w procesie tworzenia uniwerbizmów (na przykładzie języka polskiego i czeskiego), „Poradnik Językowy”, z. 2.

Vetulani G. [2001], Kolokacje werbo-nominalne jako odrębne jednostki języka $i$ ich zastosowanie, [w:] W kręgu języka polskiego. Śląsko-poznańskie kolokwia lingwistyczne, Jędrzejko E. (red.), Wydawnictwo Uniwersytetu Śląskiego, Katowice. 